\title{
Antibodies to SARS-CoV-2 and their potential for therapeutic passive immunization
}

\author{
PJ Klasse*, John P Moore
}

\author{
Department of Microbiology and Immunology, Weill Cornell Medicine, New York, \\ United States
}

\begin{abstract}
We review aspects of the antibody response to SARS-CoV-2, the causative agent of the COVID-19 pandemic. The topics we cover are relevant to immunotherapy with plasma from recovered patients, monoclonal antibodies against the viral S-protein, and soluble forms of the receptor for the virus, angiotensin converting enzyme 2. The development of vaccines against SARS-CoV-2, an essential public health tool, will also be informed by an understanding of the antibody response in infected patients. Although virus-neutralizing antibodies are likely to protect, antibodies could potentially trigger immunopathogenic events in SARS-CoV-2-infected patients or enhance infection. An awareness of these possibilities may benefit clinicians and the developers of antibody-based therapies and vaccines.
\end{abstract}

*For correspondence: pek2003@med.cornell.edu

Competing interests: The authors declare that no competing interests exist.

Funding: See page 6

Received: 20 April 2020

Accepted: 05 June 2020

Published: 23 June 2020

Reviewing editor: Evangelos J Giamarellos-Bourboulis, Attikon University Hospital, Greece

(c) Copyright Klasse and Moore. This article is distributed under the terms of the Creative Commons Attribution License, which permits unrestricted use and redistribution provided that the original author and source are credited.

\section{Introduction}

Passive immunization with plasma from patients who have seroconverted to and recovered from infection with a pathogen has a long and generally successful history. It has been used extensively against influenza virus and on a small scale during the 1995 and 2014-2015 Ebola epidemics (Brown et al., 2018; Mupapa et al., 1999; Mair-Jenkins et al., 2015; Hung et al., 2011; Luke et al., 2006). Purified polyclonal (sometimes referred to as polyvalent) immunoglobulin (lg) from convalescents has been administered prophylactically after exposure to infectious virus (Young, 2019). In recent years, highly specific and often broadly active neutralizing monoclonal antibodies (MAbs) have been developed against several viruses, as a more advanced substitute for patient plasma (Caskey et al., 2019; Corti et al., 2016; Corti et al., 2017; Walker and Burton, 2018; Wec et al., 2019; Zheng et al., 2020). These methods are now being considered for treating COVID-19, the disease caused by the SARS-CoV-2 coronavirus (Dhama et al., 2020; Jawhara, 2020; Ju et alı, 2020; Zhou and Zhao, 2020; Accorsi et al., 2020; Bloch et al., 2020; Sullivan and Roback, 2020). Several reports describe apparent benefits, with no adverse side effects, when convalescent plasma was infused into patients with SARS-CoV-1 or SARS-CoV-2 infection (Table 1; Cheng et alı, 2005; Yeh et al., 2005; Soo et al., 2004; Shen et alı, 2020; Duan et al., 2020; Zhang et al., 2020; Ahn et al., 2020). The US Food and Drug Administration has recently approved plasma immunotherapy for this purpose, and has outlined safety criteria (https://www.fda.gov/vaccines-blood-biologics/investigational-new-drug-ind-or-device-exemption-ide-process-cber/recommendations-investigational-covid-19-convalescent-plasma). To determine the efficacy of convalescent plasma to treat COVID-19, the FDA has called for randomized clinical trials and encouraged investigational new drug applications (Bloch et al., 2020; Sullivan and Roback, 2020). Here, we review aspects of the antibody response to SARS-CoV-2, which may be relevant to immunotherapy with plasma or MAbs. A major goal of viral vaccine development is the induction of strong and broadly active neutralizing antibodies (NAbs), and that goal applies also to SARS-CoV-2 (Dhama et al., 2020; Graham, 2020; Amanat and Krammer, 2020). The development of vaccines, 
an essential public health tool, will also be informed by an understanding of the antibody response during SARS-CoV-2 infection.

Assays are now available for detecting $\lg A$, $\lg M$, and $\lg$ specific for SARS-CoV-2 in patient serum, that is to demonstrate seroconversion, and also for detecting NAbs (Amanat et al., 2020; Wu et al., 2020). These techniques are rapidly evolving, and additional information on the antibody response to CoV-2 infection is emerging almost daily. Analyses of how long predictably protective titers are maintained are still lacking. They will be a priority once enough time has elapsed to allow long-term studies.

The natural history of COVID-19 and some lessons from infections with the previous SARS coronavirus (SARS-CoV-1) and the more distantly related MERS-CoV, including animal model studies, do raise some concerns about NAb-based therapies and vaccines, warranting careful surveillance by clinicians during human trials. Furthermore, certain approaches may minimize risks while preserving the benefits of passive immunization for curing COVID-19.

\section{Antibody-mediated neutralization of SARS-CoV-2}

The entry of SARS-CoV-2 into cells is initiated by the interaction of the receptor-binding domain (RBD) of the viral Spike (S) glycoprotein with the angiotensin converting enzyme-2 (ACE2), which acts as a receptor for the virus on the target cell surface (Hoffmann et al., 2020; Ou et al., 2020). The most potent NAbs are directed to the RBD and some may act by simply competing with the receptor for binding to the S-protein. Antibodies to SARS-CoV-1 and MERS-CoV generally do not cross-neutralize SARS-CoV-2; although cross-reactive antibodies are frequently detected in S-protein ELISA (Ju et al., 2020; Wu et al., 2020; Ou et al., 2020; Chen et al., 2005; Quinlan et al., 2020; Wrapp et alı, 2020). Recently, however, the S-protein-specific NAb S309, isolated from memory B cells of a patient who had recovered from CoV-1 infection in 2003, was shown to neutralize both SARS-CoV-1 and -2 potently by ligating the RBD. Cryo-electron microscopy and binding assays

Table 1. Passive immunization with convalescent plasma (CP) during SARS-CoV-1 and SARS-CoV-2 infection.

\begin{tabular}{|c|c|c|c|c|c|}
\hline Reference & Virus & Antibody source & Number of patients & Efficacy & Safety \\
\hline Cheng et al., 2005 & SARS-CoV-1 & $\begin{array}{l}\text { CP } \\
160-640 \mathrm{ml} \\
\text { Seropositive } \\
\text { titer range: } \\
160-2,560\end{array}$ & 80 patients with SARS & $\begin{array}{l}\text { Better outcome with } \\
\text { plasma before } \\
\text { than after day } 14\end{array}$ & $\begin{array}{l}\text { No immediate } \\
\text { adverse effects }\end{array}$ \\
\hline Yeh et al., 2005 & SARS-CoV-1 & $\begin{array}{l}\text { CP } \\
500 \mathrm{ml} \\
\text { IF lgG titer } \\
>640\end{array}$ & $\begin{array}{l}3 \text { hospital } \\
\text { workers with SARS }\end{array}$ & $\begin{array}{l}\text { Drop within } 24 \mathrm{hr} \\
\text { in viral load } \\
\text { from } \sim 10^{5} \text { to }<1 \\
\text { RNA copies } / \mathrm{ml}\end{array}$ & $\begin{array}{l}\text { No significant } \\
\text { side effects }\end{array}$ \\
\hline Soo et al., 2004 & SARS-CoV-1 & $\begin{array}{l}C P \\
\text { Ab titers not } \\
\text { measured }\end{array}$ & $\begin{array}{l}19 \text { (plasma) vs. } 21 \\
\text { (methylprednisolone) } \\
\text { SARS patients }\end{array}$ & $\begin{array}{l}\text { Faster release, lower } \\
\text { mortality with plasma } \\
\text { than comparator }\end{array}$ & $\begin{array}{l}\text { No immediate } \\
\text { adverse effects }\end{array}$ \\
\hline Shen et al., 2020 & SARS-CoV-2 & $\begin{array}{l}\text { CP } 400 \mathrm{ml} \\
\mathrm{Ab} \text { binding } \\
>1000 \\
\mathrm{NAb}>40\end{array}$ & 5 COVID-19 patients & $\begin{array}{l}\text { Reduced viral load, } \\
\text { clinical improvement } \\
\text { Release of } 3 / 5\end{array}$ & None reported \\
\hline Duan et al., 2020 & SARS-CoV-2 & $\begin{array}{l}\text { CP } 200 \mathrm{ml} \\
\mathrm{NAb}>640\end{array}$ & 10 COVID-19 patients & $\begin{array}{l}\text { Virus undetectable } \\
\text { in } 7 / 10 \\
\text { Varying clinical, } \\
\text { laboratory, radiological } \\
\text { improvements }\end{array}$ & $\begin{array}{l}\text { No adverse } \\
\text { effects observed }\end{array}$ \\
\hline Zhang et al., 2020 & SARS-CoV-2 & $\begin{array}{l}\mathrm{CP} 200-2,400 \mathrm{ml} \\
\mathrm{Ab} \text { not measured }\end{array}$ & 4 COVID-19 patients & $\begin{array}{l}\text { Negative PCR } \\
\text { Pulmonological } \\
\text { improvements } \\
\text { Discharge of } 3 / 4\end{array}$ & $\begin{array}{l}\text { No adverse } \\
\text { effects observed }\end{array}$ \\
\hline Ahn et al., 2020 & SARS-CoV-2 & $\begin{array}{l}\text { CP } 2 \times 250 \mathrm{ml} \\
\text { Binding lgG } \\
\text { detected by ELISA }\end{array}$ & 2 COVID-19 patients & $\begin{array}{l}\text { Reduced sputum viral load } \\
\text { Radiological and } \\
\text { clinical improvements }\end{array}$ & $\begin{array}{l}\text { No adverse } \\
\text { effects observed }\end{array}$ \\
\hline
\end{tabular}


demonstrated that the conserved S309 epitope comprises glycans and that in spite of the specificity of the Mab for the RBD, it does not interfere with ACE2 binding (Pinto et al., 2020).

The neutralizing potency of antibodies against the RBD may be determined not only by their own affinity for the S-protein but also by the affinity of the latter for ACE2, at least when they act by a competitive mechanism (Ju et alo, 2020). In this context, it is notable that the SARS-CoV-2 S-protein has a 4-20-fold higher affinity for ACE2 than its counterpart from SARS-CoV-1 $(35,37)$. Although most NAbs to SARS-CoV-1 and -2 are directed to the RBD (Pinto et al., 2020; Coughlin et alo, 2007; Greenough et al., 2005; Sui et alı, 2004; ter Meulen et alı, 2006; van den Brink et al., 2005; Zhu et al., 2007), some antibodies that recognize the SARS-CoV-1 S2 fragment can also neutralize (Duan et al., 2005; Elshabrawy et al., 2012). In addition, antibodies to the ectodomain of another surface-exposed SARS-CoV-1 protein, Orf3a, are also reported to have neutralizing activity, while antibodies to the $M$ and $E$ proteins can potentiate neutralization (Akerström et alo, 2006; Buchholz et al., 2004). Whether SARS-CoV-2 is similar to SARS-CoV-1 in all these respects remains to be determined. Nonetheless, passive and active immunization approaches to COVID-19 are generally focused on NAbs against the S1-protein.

\section{The kinetics of NAb and other antibody responses in SARS-CoV infection}

The information on the antibody responses elicited in COVID-19 patients is growing fast, but none is yet available about the longevity of the immunity. Data on SARS-CoV-1 infection may, however, be informative in that respect. Surprisingly, the NAb response in patients who later succumbed to the infection has been found to be faster than in those who recovered; in the patients who later died, the titers had peaked around day 15 after the onset of symptoms, whereas similar titers and extents of neutralization were reached only after day 20 in the patients who recovered (Zhang et alo, 2006; Ho et al., 2005). The NAb titers in the moribund patients declined or disappeared after the early rise, as their conditions deteriorated towards death (Zhang et alo, 2006). It is unknown whether this titer loss reflects an inability to produce antibodies due to lymphocyte losses. As NAb titers rise, however, viral loads decline, presumably because virus replication diminishes (Wölfel et al., 2020; To et al., 2020). These findings do not exclude the possibility that the initial viral loads, before NAbs emerged, were particularly high and stimulated stronger and earlier antibody responses in the patients who subsequently became most severely affected.

In plasma collected from 175 patients who had recovered from mild COVID-19, NAb and S-binding-antibody titers correlated positively with age and CRP (C-reactive protein) levels, but negatively with lymphocyte counts; and the NAbs did not cross-neutralize SARS-CoV-1 (Wu et al., 2020). Since no severe cases were included and viral loads were not monitored, it is unclear what promoted the NAb responses within the patient cohort in which antibody titers, age (range 16-85 years), lymphopenia, and inflammation were associated. The positive correlation between NAb responses and age contrasts with a general decline in the vigor of new B-cell responses in the elderly (Siegrist and Aspinall, 2009), but raises the question whether the pre-response viral load was correlated with age, which in turn correlates with disease severity. Other studies have shown higher binding-antibody titers to the nucleocapsid protein $\mathrm{N}$ in patients who recovered than in those who did not (Wu et al., 2020; Leung et al., 2004). Such antibodies to the N-protein, which is internal and thus not exposed on the surface of the virion, completely lack neutralizing capacity but their production might reflect the strength of T-helper cell responses (Klasse et alo, 2012).

\section{NAb immunotherapy against SARS-CoV-1 and SARS-CoV-2}

Will passive immunization with plasma from convalescent patients be beneficial for treating COVID19? Anti-S antibodies seem to protect against lethal CoV challenge and clear the virus in mice and ferrets (Du et al., 2008a; Du et alo, 2007; Du et al., 2008b; Fett et alı, 2013). In a small experiment, SARS-CoV-2 infection reportedly protected against a second challenge of macaques, which was attributed to the development of protective antibodies (Bao et al., 2020). The outcome of human clinical trials will, of course, outweigh animal-model experiments.

No significant adverse reactions were noted when plasma with high NAb titers were given to SARS-CoV-1 patients; benefits such as lower viral loads and earlier release from hospital were noted in retrospective analyses (Cheng et al., 2005; Yeh et al., 2005; Soo et al., 2004; Table 1). Recently, 
five critically ill COVID-19 patients were transfused at 10-22 days post-admission with a pool of plasma derived from five convalescent patients; the RBD-binding antibody endpoint titers in ELISA were $>1000$, and the neutralization endpoint titers were $>40$ (Shen et al., 2020). All the patients (36-65 years; three male, two female) were receiving mechanical ventilation. After plasma transfusion, body temperatures normalized, while organ-failure and respiratory-function scores improved to various extents. Nasopharyngeal viral loads decreased and became undetectable within 12 days in all five patients, while SARS-CoV-2 ELISA and NAb titers increased, reflecting the antibody-content of the transfused plasma. Thus, in this preliminary and necessarily uncontrolled case series of five critically ill COVID-19 patients with acute respiratory distress syndrome (ARDS), the transfusion of NAb-containing convalescent plasma was associated with improved clinical status (Shen et alı, 2020). A subsequent larger study yielded similar results: ten patients with severe COVID-19 received $200 \mathrm{~mL}$ of convalescent plasma obtained from recently recovered donors with NAb inhibitory-dilution factors $>$ 640. Three days later, clinical, pulmonary-radiological, and laboratory parameters were improved, the latter including oxyhemoglobin saturation, lymphocyte counts, and C-reactive protein levels; viral loads in serum became undetectable in seven patients (Duan et al., 2020; see also additional smaller studies in Table 1). Overall, these studies showed plasma transfusion to be well tolerated. Although beneficial effects were reported, they could not be proven because the studies were not controlled and included other antiviral interventions.

\section{Can antibodies contribute to SARS pathogenesis?}

Strategies for passive and active immunization to combat and prevent SARS-CoV-2 infection should take into account the pathogenesis of COVID-19, which can lead to death. The inflammatory response to SARS-CoV-2 is thought to drive or at least exacerbate the disease process, particularly during the second week after infection becomes symptomatic. How may these immune responses that modulate pathogenesis be affected by NAbs?

The lethal coronaviruses cause fatal acute lung injury (ALI) by driving hypercytokinemia and aggressive inflammation through incompletely understood mechanisms. In macaque models of SARS-CoV-1 infection and passive or active immunization, lgG specific for the S-protein was reported to exacerbate $A \mathrm{LI}$ by counteracting inflammation-resolving responses, abrogating woundhealing, promoting monocyte chemoattractant peptide-1 (MCP-1) and interleukin-8 (IL-8) production, and increasing proinflammatory monocyte and macrophage recruitment (Liu et al., 2019). Likewise, in human patients who died of SARS-CoV-1 infection, pulmonary proinflammatory macrophages accumulated in the lungs, whereas wound-healing macrophages were absent (Liu et al., 2019). Moreover, two observations noted above raise questions about the causal relationship between antibodies and severity of infection: NAb responses were faster in the patients who later died than in those who recovered (Zhang et al., 2006; Ho et al., 2005; Liu et al., 2019), and older patients who had recovered from mild COVID-19, had significantly stronger NAb and S-protein-binding antibody responses than younger ones, whereas higher age is a major risk factor for lethal COVID-19 (Wu et al., 2020).

In vitro, sera from subsequently deceased patients enhanced SARS-CoV-1 induced MCP-1 and IL8 production by human monocyte-derived wound-healing macrophages, whereas blockade of the $\mathrm{Fc} \gamma \mathrm{R}$ receptor reduced these effects (Liu et alı, 2019). One must be prudent when extrapolating from a macaque model of SARS-CoV-1 infection to human COVID-19 patients, but the antibody response to these lethal coronaviruses might play a role in disease progression, perhaps by formation of immune complexes, and by promoting macrophage infiltration and sustained inflammation. We hypothesize that there may be a causal link between seroconversion and the rapid deterioration that can take place in the second week after the first symptoms, but this remains to be established.

Other reports suggest that anti-S and other CoV-specific antibodies have pathogenic effects in animal models. Thus, multiple CoV vaccines were associated with an increase in eosinophilic proinflammatory pulmonary responses upon challenge of the immunized animals (Bolles et al., 2011; Honda-Okubo et alı, 2015; Iwata-Yoshikawa et al., 2014). Previous SARS-CoV-1 infection limited virus replication in African green monkeys but not lung inflammation, when the animals were re-challenged with the same virus (Clay et al., 2012). It has not been determined which factors, such as viral dose and the extent of the innate and adaptive immune responses, yield these problematic effects. A particularly important knowledge gap is whether certain specificities and other properties of antibodies are responsible. 
Pre-existing serum antibodies against influenza antigens were consistently associated with severe illness in patients during the 2009 influenza A H1N1 pandemic (To et al., 2012; Monsalvo et al., 2011). Of note is that those antibodies did not neutralize influenza virus (To et al., 2012) and that immune complex formation was implicated as a pathogenic trigger (Monsalvo et al., 2011). Whether these observations are linked to the findings reported by Liu et al. remains to be seen (Liu et al., 2019).

\section{Antibody-dependent enhancement of infection (ADE)}

Antibodies can also exacerbate viral infection by different mechanisms that have long been described (Halstead, 1982). In the vaccine context, infection by alpha- and flaviviruses (such as Dengue and Zika viruses) is enhanced when the antibody occupancy on the virion-surface epitopes falls below a critical threshold (Pierson and Diamond, 2015). This is the stoichiometric condition of an Fc-receptor-dependent form of ADE: the same antibodies that mediate ADE can neutralize and protect at higher occupancies on virions; alternatively, non-NAbs binding to epitopes exposed on the virion surface to antigens that are not functional for mediating entry may confer ADE (Pierson and Diamond, 2015; Klasse, 2014). The in vitro observations of ADE seem to account for the unfortunate outcome of recent Dengue vaccine trials with examples of worsened disease post-infection (Hurtado-Monzón et al., 2020). ADE has been reported in the coronavirus literature, although most studies do not suggest that it will be as problematic as for alpha- and flaviviruses (Jaume et al., 2011; Kam et al., 2007; Peeples, 2020; Wan et al., 2020; Wang et al., 2014; Wang et al., 2016; Diamond and Pierson, 2020; de Alwis et al., 2020; Burton and Walker, 2020). An exception is a study of vaccinia-vectored immunization of kittens with the $\mathrm{S}$ protein of the coronavirus feline infectious peritonitis virus. The vaccine induced NAbs poorly. After challenge with the infectious virus, deaths occurred sooner in the S-protein-vaccine group than in the vaccinia-only control group (Diamond and Pierson, 2020; Vennema et al., 1990).

Particular problems of ADE could arise in the face of an ongoing epidemic through NAbs at subprotective levels, whether after incomplete vaccination courses or with poor and rapidly declining vaccine responses, as well as after passive immunization because of insufficient efficacy of NAbs in plasma or in purified polyclonal Ig and of MAbs.

One recent report described an unusual mechanism of MERS-CoV-infection enhancement in vitro, whereby the antibody binding to the S protein RBD promoted endocytic uptake by engaging with an Fc-receptor and triggered fusion by inducing a conformational change (Jaume et al., 2011). It augurs well for vaccine development, however, that a SARS-CoV-2 RBD used as an immunogen elicited strong NAb responses in rats, without any ADE (Quinlan et al., 2020). These topics will, no doubt, be investigated thoroughly as much-needed SARS-CoV-2 vaccines undergo pre-clinical and clinical testing.

\section{Possible improvements to immunotherapy}

How could therapeutic interventions be improved so as to preserve the capacity of the infused NAbs to reduce virus replication while preventing the possible induction of fatal ALI through promotion of IL-8 and MCP-1 production and inflammatory macrophage accumulation? One precaution would be to administer NAbs with Fc deletions. In principle, this could be accomplished by enzymatic treatment of polyclonal lgGs purified from plasma to generate bivalent $F\left(a b^{\prime}\right)$ two fragments. But in practice this would probably be too onerous. More feasible is the genetic engineering of neutralizing MAbs to eliminate the ability of the Fc-domains to bind activating FcR:s. Although such mutations would also eliminate potentially beneficial Fc-mediated effects such as ADCC, there is no evidence that these effector functions play a role in reducing viral load. For that goal, virus neutralization may be necessary and sufficient, at least during the COVID-19 acute phase.

An alternative neutralizing intervention, which eliminates some risks associated with polyclonal and monoclonal antibodies, is the use of a soluble, recombinant form of the ACE2 receptor, which is potent (nM range) and effective (depending on target cells) at blocking SARS-CoV-2 infection in vitro (Lei et al., 2020). Since the SARS-CoV-2 S-protein has a 4-20-fold higher affinity than the SARSCoV-1 S-protein for ACE2, it may be more sensitive to this particular intervention, at least under some conditions of infection (Wrapp et al., 2020; Walls et al., 2020). Other advantages of these constructs are their potency and potential breadth of action against new viral variants. But if Fc- 
receptor ligation is pathogenic (Liu et al., 2019), methods of increasing avidity other than fusing the soluble receptor to the Fc portion of lgG could be explored. The effects on angiotensin activation and its pharmacological inhibition may also need to be evaluated (Hoffmann et al., 2020; Aronson and Ferner, 2020).

\section{Conclusions}

Plasma infusion as therapy for COVID-19 is a stop-gap measure that is now being used in a medical emergency. Within the next year, effective drugs are likely to emerge, and they may well include highly potent and specific MAbs to the SARS-CoV-2 S-protein. Animal experiments, particularly in macaques, will be valuable for comparing the capacity of different monoclonal and polyclonal antibodies, including combinations, or of recombinant receptor mimics, to clear SARS-CoV-2 infection. Ideally, the intervention should permit or even promote the emergence of favorable innate responses and the resolution of inflammation (Nathan and Ding, 2010). Given the urgency of the COVID-19 pandemic, however, it may be impossible to perform such studies before human trials. Furthermore, differences in Fc-receptor biology may invalidate some extrapolations of antibody effects from macaques to humans (Bournazos and Ravetch, 2017). In these circumstances, an awareness of what has occurred in other viral infections, particularly with SARS-CoV-1, as well as what is now being published on SARS-CoV-2, may guide both treatment strategies and the development of antibody-based vaccines (Peeples, 2020; Tseng et al., 2012; Agrawal et al., 2016). Prospective or retrospective analyses of how the binding-antibody and NAb titers of transfused plasmas are associated with clinical improvements should also guide both MAb-based therapies and vaccine evaluation. If apparently antibody-mediated adverse events do occur, they too should help to improve these important public health measures against the COVID-19 pandemic.

\section{Acknowledgements}

This work was supported by National Institutes of Health grants R01 Al36082 and P01 Al110657 and by Bill and Melinda Gates Foundation grants OPP1132237 and INV-002022. The Authors have no conflicts of interest to disclose.

\section{Additional information}

Funding

\begin{tabular}{lll} 
Funder & Grant reference number & Author \\
\hline National Institutes of Health & R01 Al36082 & John Moore \\
\hline National Institutes of Health & P01 Al110657 & John Moore \\
\hline $\begin{array}{l}\text { Bill and Melinda Gates Foun- } \\
\text { dation }\end{array}$ & OPP1132237 & John Moore \\
\hline $\begin{array}{l}\text { Bill and Melinda Gates Foun- } \\
\text { dation }\end{array}$ & INV-002022 & John Moore \\
\hline
\end{tabular}

The authors declare that the funders had no role in study design, data collection or interpretation, or the decision to submit the work for publication.

Author ORCIDs

PJ Klasse (iD https://orcid.org/0000-0001-8222-278X

\section{References}

Accorsi P, Berti P, Angelis de . 2020. Position paper on the preparation of immune plasma to be used in the treatment of patients with COVID-19. Blood Transfusion = Trasfusione Del Sangue 18:163-166. DOI: https:// doi.org/10.1016/j.transci.2020.102817

Agrawal AS, Tao X, Algaissi A, Garron T, Narayanan K, Peng BH, Couch RB, Tseng CT. 2016. Immunization with inactivated Middle East Respiratory Syndrome coronavirus vaccine leads to lung immunopathology on 
challenge with live virus. Human Vaccines \& Immunotherapeutics 12:2351-2356. DOI: https://doi.org/10.1080/ 21645515.2016.1177688, PMID: 27269431

Ahn JY, Sohn Y, Lee SH, Cho Y, Hyun JH, Baek YJ, Jeong SJ, Kim JH, Ku NS, Yeom J-S, Roh J, Ahn MY, Chin BS, Kim YS, Lee H, Yong D, Kim HO, Kim S, Choi JY. 2020. Use of convalescent plasma therapy in two COVID-19 patients with acute respiratory distress syndrome in Korea. Journal of Korean Medical Science 35:e149. DOI: https://doi.org/10.3346/jkms.2020.35.e149

Akerström S, Tan YJ, Mirazimi A. 2006. Amino acids 15-28 in the ectodomain of SARS coronavirus 3a protein induces neutralizing antibodies. FEBS Letters 580:3799-3803. DOI: https://doi.org/10.1016/j.febslet.2006.06. 002, PMID: 16781713

Amanat F, Stadlbauer D, Strohmeier S, Nguyen THO, Chromikova V, McMahon M, Jiang K, Arunkumar GA, Jurczyszak D, Polanco J, Bermudez-Gonzalez M, Kleiner G, Aydillo T, Miorin L, Fierer DS, Lugo LA, Kojic EM, Stoever J, Liu STH, Cunningham-Rundles C, et al. 2020. A serological assay to detect SARS-CoV-2 seroconversion in humans. Nature Medicine 5:12. DOI: https://doi.org/10.1038/s41591-020-0913-5

Amanat F, Krammer F. 2020. SARS-CoV-2 vaccines: status report. Immunity 52:583-589. DOI: https://doi.org/10. 1016/j.immuni.2020.03.007

Aronson JK, Ferner RE. 2020. Drugs and the renin-angiotensin system in covid-19. BMJ 369:m1313. DOI: https://doi.org/10.1136/bmj.m1313, PMID: 32241880

Bao L, Wei Deng W, Gao H, Xiao C, Liu J, Xue J, Lv Q, Liu J, Yu P, Xu Y, Qi F, Qu Y, Li F, Xiang Z, Yu H, Gong S, Liu M, Wang G, Wang S, Song Z, et al. 2020. Reinfection could not occur in SARS-CoV-2 infected rhesus macaques. bioRxiv. DOI: https://doi.org/10.1101/2020.03.13.990226

Bloch EM, Shoham S, Casadevall A. 2020. Deployment of convalescent plasma for the prevention and treatment of COVID-19. The Journal of Clinical Investigation 18:138745. DOI: https://doi.org/10.1172/JCl138745

Bolles M, Deming D, Long K, Agnihothram S, Whitmore A, Ferris M, Funkhouser W, Gralinski L, Totura A, Heise M, Baric RS. 2011. A double-inactivated severe acute respiratory syndrome coronavirus vaccine provides incomplete protection in mice and induces increased eosinophilic proinflammatory pulmonary response upon challenge. Journal of Virology 85:12201-12215. DOI: https://doi.org/10.1128/JVI.06048-11, PMID: 21937658

Bournazos S, Ravetch JV. 2017. Anti-retroviral antibody FcyR-mediated effector functions. Immunological Reviews 275:285-295. DOI: https://doi.org/10.1111/imr.12482, PMID: 28133801

Brown JF, Dye JM, Tozay S, Jeh-Mulbah G, Wohl DA, Fischer WA, Cunningham CK, Rowe K, Zacharias P, van Hasselt J, Norwood DA, Thielman NM, Zak SE, Hoover DL. 2018. Anti-Ebola virus antibody levels in convalescent plasma and viral load after plasma infusion in patients with ebola virus disease. The Journal of Infectious Diseases 218:555-562. DOI: https://doi.org/10.1093/infdis/jiy199, PMID: 29659889

Buchholz UJ, Bukreyev A, Yang L, Lamirande EW, Murphy BR, Subbarao K, Collins PL. 2004. Contributions of the structural proteins of severe acute respiratory syndrome coronavirus to protective immunity. PNAS 101:98049809. DOl: https://doi.org/10.1073/pnas.0403492101, PMID: 15210961

Burton DR, Walker LM. 2020. Rational vaccine design in the time of COVID-19. Cell Host \& Microbe 27:695-698. DOI: https://doi.org/10.1016/j.chom.2020.04.022, PMID: 32407707

Caskey M, Klein F, Nussenzweig MC. 2019. Broadly neutralizing anti-HIV-1 monoclonal antibodies in the clinic. Nature Medicine 25:547-553. DOI: https://doi.org/10.1038/s41591-019-0412-8, PMID: 30936546

Chen Z, Zhang L, Qin C, Ba L, Yi CE, Zhang F, Wei Q, He T, Yu W, Yu J, Gao H, Tu X, Gettie A, Farzan M, Yuen KY, Ho DD. 2005. Recombinant modified vaccinia virus Ankara expressing the spike glycoprotein of severe acute respiratory syndrome coronavirus induces protective neutralizing antibodies primarily targeting the receptor binding region. Journal of Virology 79:2678-2688. DOI: https://doi.org/10.1128/JVI.79.5.2678-2688. 2005, PMID: 15708987

Cheng Y, Wong R, Soo YO, Wong WS, Lee CK, Ng MH, Chan P, Wong KC, Leung CB, Cheng G. 2005. Use of convalescent plasma therapy in SARS patients in Hong Kong. European Journal of Clinical Microbiology \& Infectious Diseases 24:44-46. DOI: https://doi.org/10.1007/s10096-004-1271-9, PMID: 15616839

Clay C, Donart N, Fomukong N, Knight JB, Lei W, Price L, Hahn F, Van Westrienen J, Harrod KS. 2012. Primary severe acute respiratory syndrome coronavirus infection limits replication but not lung inflammation upon homologous rechallenge. Journal of Virology 86:4234-4244. DOI: https://doi.org/10.1128/JVI.06791-11, PMID: 22345460

Corti D, Passini N, Lanzavecchia A, Zambon M. 2016. Rapid generation of a human monoclonal antibody to combat middle east respiratory syndrome. Journal of Infection and Public Health 9:231-235. DOI: https://doi. org/10.1016/j.jiph.2016.04.003, PMID: 27102927

Corti D, Cameroni E, Guarino B, Kallewaard NL, Zhu Q, Lanzavecchia A. 2017. Tackling influenza with broadly neutralizing antibodies. Current Opinion in Virology 24:60-69. DOI: https://doi.org/10.1016/j.coviro.2017.03 002, PMID: 28527859

Coughlin M, Lou G, Martinez O, Masterman SK, Olsen OA, Moksa AA, Farzan M, Babcook JS, Prabhakar BS. 2007. Generation and characterization of human monoclonal neutralizing antibodies with distinct binding and sequence features against SARS coronavirus using XenoMouse. Virology 361:93-102. DOI: https://doi.org/10. 1016/j.virol.2006.09.029, PMID: 17161858

de Alwis R, Chen S, Gan ES, Ooi EE. 2020. Impact of immune enhancement on Covid-19 polyclonal hyperimmune globulin therapy and vaccine development. EBioMedicine 55:102768. DOI: https://doi.org/10. 1016/j.ebiom.2020.102768, PMID: 32344202

Dhama K, Sharun K, Tiwari R, Dadar M, Malik YS, Singh KP, Chaicumpa W. 2020. COVID-19, an emerging coronavirus infection: advances and prospects in designing and developing vaccines, immunotherapeutics, and 
therapeutics. Human Vaccines \& Immunotherapeutics 57:1-7. DOI: https://doi.org/10.1080/21645515.2020. 1735227

Diamond MS, Pierson TC. 2020. The challenges of vaccine development against a new virus during a pandemic. Cell Host \& Microbe 27:699-703. DOI: https://doi.org/10.1016/j.chom.2020.04.021, PMID: 32407708

Du L, Zhao G, He Y, Guo Y, Zheng BJ, Jiang S, Zhou Y. 2007. Receptor-binding domain of SARS-CoV spike protein induces long-term protective immunity in an animal model. Vaccine 25:2832-2838. DOI: https://doi. org/10.1016/j.vaccine.2006.10.031, PMID: 17092615

Du L, Zhao G, Lin Y, Sui H, Chan C, Ma S, He Y, Jiang S, Wu C, Yuen KY, Jin DY, Zhou Y, Zheng BJ. 2008 . Intranasal vaccination of recombinant adeno-associated virus encoding receptor-binding domain of severe acute respiratory syndrome coronavirus (SARS-CoV) spike protein induces strong mucosal immune responses and provides long-term protection against SARS-CoV infection. The Journal of Immunology 180:948-956. DOI: https://doi.org/10.4049/jimmunol.180.2.948, PMID: 18178835

Du L, Zhao G, Lin Y, Chan C, He Y, Jiang S, Wu C, Jin DY, Yuen KY, Zhou Y, Zheng BJ. 2008b. Priming with rAAV encoding RBD of SARS-CoV S protein and boosting with RBD-specific peptides for T cell epitopes elevated humoral and cellular immune responses against SARS-CoV infection. Vaccine 26:1644-1651. DOI: https://doi. org/10.1016/j.vaccine.2008.01.025, PMID: 18289745

Duan J, Yan X, Guo X, Cao W, Han W, Qi C, Feng J, Yang D, Gao G, Jin G. 2005. A human SARS-CoV neutralizing antibody against epitope on S2 protein. Biochemical and Biophysical Research Communications 333:186-193. DOl: https://doi.org/10.1016/j.bbrc.2005.05.089

Duan K, Liu B, Li C, Zhang H, Yu T, Qu J, Zhou M, Chen L, Meng S, Hu Y, Peng C, Yuan M, Huang J, Wang Z, Yu J, Gao X, Wang D, Yu X, Li L, Zhang J, et al. 2020. Effectiveness of convalescent plasma therapy in severe COVID-19 patients. PNAS 117:9490-9496. DOI: https://doi.org/10.1073/pnas.2004168117, PMID: 32253318

Elshabrawy HA, Coughlin MM, Baker SC, Prabhakar BS. 2012. Human monoclonal antibodies against highly conserved HR1 and HR2 domains of the SARS-CoV spike protein are more broadly neutralizing. PLOS ONE 7: e50366. DOI: https://doi.org/10.1371/journal.pone.0050366, PMID: 23185609

Fett C, DeDiego ML, Regla-Nava JA, Enjuanes L, Perlman S. 2013. Complete protection against severe acute respiratory syndrome coronavirus-mediated lethal respiratory disease in aged mice by immunization with a mouse-adapted virus lacking E protein. Journal of Virology 87:6551-6559. DOI: https://doi.org/10.1128/JVI. 00087-13, PMID: 23576515

Graham BS. 2020. Rapid COVID-19 vaccine development. Science 368:945-946. DOI: https://doi.org/10.1126/ science.abb8923, PMID: 32385100

Greenough TC, Babcock GJ, Roberts A, Hernandez HJ, Thomas WD, Coccia JA, Graziano RF, Srinivasan M, Lowy I, Finberg RW, Subbarao K, Vogel L, Somasundaran M, Luzuriaga K, Sullivan JL, Ambrosino DM. 2005. Development and characterization of a severe acute respiratory syndrome-associated coronavirus-neutralizing human monoclonal antibody that provides effective immunoprophylaxis in mice. The Journal of Infectious Diseases 191:507-514. DOI: https://doi.org/10.1086/427242, PMID: 15655773

Halstead SB. 1982. Immune enhancement of viral infection. Progress in Allergy 31:301-364. PMID: 6292921

Ho MS, Chen WJ, Chen HY, Lin SF, Wang MC, Di J, Lu YT, Liu CL, Chang SC, Chao CL, King CC, Chiou JM, Su IJ, Yang JY. 2005. Neutralizing antibody response and SARS severity. Emerging Infectious Diseases 11:17301737. DOI: https://doi.org/10.3201/eid1111.040659, PMID: 16318725

Hoffmann M, Kleine-Weber H, Schroeder S, Krüger N, Herrler T, Erichsen S, Schiergens TS, Herrler G, Wu NH, Nitsche A, Müller MA, Drosten C, Pöhlmann S. 2020. SARS-CoV-2 cell entry depends on ACE2 and TMPRSS2 and is blocked by a clinically proven protease inhibitor. Cell 181:271-280. DOI: https://doi.org/10.1016/j.cell. 2020.02.052, PMID: 32142651

Honda-Okubo Y, Barnard D, Ong CH, Peng BH, Tseng CT, Petrovsky N. 2015. Severe acute respiratory syndrome-associated coronavirus vaccines formulated with Delta inulin adjuvants provide enhanced protection while ameliorating lung eosinophilic immunopathology. Journal of Virology 89:2995-3007. DOl: https://doi. org/10.1128/JVI.02980-14, PMID: 25520500

Hung IF, To KK, Lee CK, Lee KL, Chan K, Yan WW, Liu R, Watt CL, Chan WM, Lai KY, Koo CK, Buckley T, Chow FL, Wong KK, Chan HS, Ching CK, Tang BS, Lau CC, Li IW, Liu SH, et al. 2011. Convalescent plasma treatment reduced mortality in patients with severe pandemic influenza A (H1N1) 2009 virus infection. Clinical Infectious Diseases 52:447-456. DOI: https://doi.org/10.1093/cid/ciq106, PMID: 21248066

Hurtado-Monzón AM, Cordero-Rivera CD, Farfan-Morales CN, Osuna-Ramos JF, De Jesús-González LA, Reyes-Ruiz JM, Ángel RM. 2020. The role of anti-flavivirus humoral immune response in protection and pathogenesis. Reviews in Medical Virology 65:e2100. DOI: https://doi.org/10.1002/rmv.2100

Iwata-Yoshikawa N, Uda A, Suzuki T, Tsunetsugu-Yokota Y, Sato Y, Morikawa S, Tashiro M, Sata T, Hasegawa H, Nagata N. 2014. Effects of Toll-like receptor stimulation on eosinophilic infiltration in lungs of BALB/c mice immunized with UV-inactivated severe acute respiratory syndrome-related coronavirus vaccine. Journal of Virology 88:8597-8614. DOI: https://doi.org/10.1128/JVI.00983-14, PMID: 24850731

Jaume M, Yip MS, Cheung CY, Leung HL, Li PH, Kien F, Dutry I, Callendret B, Escriou N, Altmeyer R, Nal B, Daëron M, Bruzzone R, Peiris JS. 2011. Anti-severe acute respiratory syndrome coronavirus spike antibodies trigger infection of human immune cells via a $\mathrm{pH}$ - and cysteine protease-independent fcyr pathway. Journal of Virology 85:10582-10597. DOI: https://doi.org/10.1128/JVI.00671-11, PMID: 21775467

Jawhara S. 2020. Could intravenous immunoglobulin collected from recovered coronavirus patients protect against COVID-19 and strengthen the immune system of new patients? International Journal of Molecular Sciences 21:2272. DOl: https://doi.org/10.3390/ijms21072272 
Ju B, Zhang Q, Ge J, Wang R, Sun J, Ge X, Yu J, Shan S, Zhou B, Song S, Tang X, Yu J, Lan J, Yuan J, Wang H, Zhao J, Zhang S, Wang Y, Shi X, Liu L, et al. 2020. Human neutralizing antibodies elicited by SARS-CoV-2 infection. Nature. DOI: https://doi.org/10.1038/s41586-020-2380-z, PMID: 32454513

Kam YW, Kien F, Roberts A, Cheung YC, Lamirande EW, Vogel L, Chu SL, Tse J, Guarner J, Zaki SR, Subbarao K, Peiris M, Nal B, Altmeyer R. 2007. Antibodies against trimeric S glycoprotein protect hamsters against SARSCoV challenge despite their capacity to mediate FcgammaRll-dependent entry into B cells in vitro. Vaccine $\mathbf{2 5}$ 729-740. DOl: https://doi.org/10.1016/j.vaccine.2006.08.011, PMID: 17049691

Klasse PJ, Sanders RW, Cerutti A, Moore JP. 2012. How can HIV-type-1-Env immunogenicity be improved to facilitate antibody-based vaccine development? AIDS Research and Human Retroviruses 28:1-15. DOI: https:// doi.org/10.1089/aid.2011.0053, PMID: 21495876

Klasse PJ. 2014. Neutralization of virus infectivity by antibodies: old problems in new perspectives. Advances in Biology 2014::1-24. DOI: https://doi.org/10.1155/2014/157895, PMID: 27099867

Lei C, Qian K, Li T, Zhang S, Fu W, Ding M, Hu S. 2020. Neutralization of SARS-CoV-2 spike pseudotyped virus by recombinant ACE2-lg. Nature Communications 11:2070. DOI: https://doi.org/10.1038/s41467-020-16048-4, PMID: 32332765

Leung DT, Tam FC, Ma CH, Chan PK, Cheung JL, Niu H, Tam JS, Lim PL. 2004. Antibody response of patients with severe acute respiratory syndrome (SARS) targets the viral nucleocapsid. The Journal of Infectious Diseases 190:379-386. DOI: https://doi.org/10.1086/422040, PMID: 15216476

Liu L, Wei Q, Lin Q, Fang J, Wang H, Kwok H, Tang H, Nishiura K, Peng J, Tan Z, Wu T, Cheung K-W, Chan K-H, Alvarez X, Qin C, Lackner A, Perlman S, Yuen K-Y, Chen Z. 2019. Anti-spike IgG causes severe acute lung injury by skewing macrophage responses during acute SARS-CoV infection. JCI Insight 4:123158. DOI: https://doi. org/10.1172/jci.insight.123158

Luke TC, Kilbane EM, Jackson JL, Hoffman SL. 2006. Meta-analysis: convalescent blood products for Spanish influenza pneumonia: a future H5N1 treatment? Annals of Internal Medicine 145:599-609. DOI: https://doi.org/ 10.7326/0003-4819-145-8-200610170-00139, PMID: 16940336

Mair-Jenkins J, Saavedra-Campos M, Baillie JK, Cleary P, Khaw FM, Lim WS, Makki S, Rooney KD, Nguyen-VanTam JS, Beck CR, Convalescent Plasma Study Group. 2015. The effectiveness of convalescent plasma and hyperimmune immunoglobulin for the treatment of severe acute respiratory infections of viral etiology: a systematic review and exploratory meta-analysis. Journal of Infectious Diseases 211:80-90. DOI: https://doi. org/10.1093/infdis/jiu396, PMID: 25030060

Monsalvo AC, Batalle JP, Lopez MF, Krause JC, Klemenc J, Hernandez JZ, Maskin B, Bugna J, Rubinstein C, Aguilar L, Dalurzo L, Libster R, Savy V, Baumeister E, Aguilar L, Cabral G, Font J, Solari L, Weller KP, Johnson J, et al. 2011. Severe pandemic 2009 H1N1 influenza disease due to pathogenic immune complexes. Nature Medicine 17:195-199. DOI: https://doi.org/10.1038/nm.2262

Mupapa K, Massamba M, Kibadi K, Kuvula K, Bwaka A, Kipasa M, Colebunders R, Muyembe-Tamfum JJ. 1999. Treatment of ebola hemorrhagic fever with blood transfusions from convalescent patients international scientific and technical committee. The Journal of Infectious Diseases 179:S18-S23. DOI: https://doi.org/10. 1086/514298, PMID: 9988160

Nathan C, Ding A. 2010. Nonresolving inflammation. Cell 140:871-882. DOl: https://doi.org/10.1016/j.cell.2010. 02.029, PMID: 20303877

Ou X, Liu Y, Lei X, Li P, Mi D, Ren L, Guo L, Guo R, Chen T, Hu J, Xiang Z, Mu Z, Chen X, Chen J, Hu K, Jin O, Wang J, Qian Z. 2020. Characterization of spike glycoprotein of SARS-CoV-2 on virus entry and its immune cross-reactivity with SARS-CoV. Nature Communications 11:1620. DOI: https://doi.org/10.1038/s41467-02015562-9, PMID: 32221306

Peeples L. 2020. News feature: avoiding pitfalls in the pursuit of a COVID-19 vaccine. PNAS. pii: 117:82188221. DOI: https://doi.org/10.1073/pnas.2005456117, PMID: 32229574

Pierson TC, Diamond MS. 2015. A game of numbers: the stoichiometry of antibody-mediated neutralization of Flavivirus infection. Progress in Molecular Biology and Translational Science 129:141-166. DOI: https://doi.org/ 10.1016/bs.pmbts.2014.10.005, PMID: 25595803

Pinto D, Park YJ, Beltramello M, Walls AC, Tortorici MA, Bianchi S, Jaconi S, Culap K, Zatta F, De Marco A, Peter A, Guarino B, Spreafico R, Cameroni E, Case JB, Chen RE, Havenar-Daughton C, Snell G, Telenti A, Virgin HW, et al. 2020. Cross-neutralization of SARS-CoV-2 by a human monoclonal SARS-CoV antibody. Nature. DOI: https://doi.org/10.1038/s41586-020-2349-y, PMID: 32422645

Quinlan BD, Mou H, Zhang L, Guo Y, He W, Ojha A, Parcells MS, Luo G, Li W, Zhong G, Choe H, Farzan M. 2020. The SARS-CoV-2 receptor-binding domain elicits a potent neutralizing response without antibodydependent enhancement. bioRxiv. DOI: https://doi.org/10.1101/2020.04.10.036418.

Shen C, Wang Z, Zhao F, Yang Y, Li J, Yuan J, Wang F, Li D, Yang M, Xing L, Wei J, Xiao H, Yang Y, Qu J, Qing L, Chen L, Xu Z, Peng L, Li Y, Zheng H, et al. 2020. Treatment of 5 critically ill patients with COVID-19 with convalescent plasma. JAMA 323:1582. DOI: https://doi.org/10.1001/jama.2020.4783

Siegrist CA, Aspinall R. 2009. B-cell responses to vaccination at the extremes of age. Nature Reviews Immunology 9:185-194. DOI: https://doi.org/10.1038/nri2508, PMID: 19240757

Soo YO, Cheng Y, Wong R, Hui DS, Lee CK, Tsang KK, Ng MH, Chan P, Cheng G, Sung JJ. 2004. Retrospective comparison of convalescent plasma with continuing high-dose methylprednisolone treatment in SARS patients. Clinical Microbiology and Infection 10:676-678. DOI: https://doi.org/10.1111/j.1469-0691.2004.00956.x, PMID: 15214887

Sui J, Li W, Murakami A, Tamin A, Matthews LJ, Wong SK, Moore MJ, Tallarico AS, Olurinde M, Choe H, Anderson LJ, Bellini WJ, Farzan M, Marasco WA. 2004. Potent neutralization of severe acute respiratory 
syndrome (SARS) coronavirus by a human mAb to S1 protein that blocks receptor association. PNAS 101:25362541. DOI: https://doi.org/10.1073/pnas.0307140101, PMID: 14983044

Sullivan HC, Roback JD. 2020. Convalescent plasma: therapeutic hope or hopeless strategy in the SARS-CoV-2 pandemic. Transfusion Medicine Reviews S0887-7963:30025. DOI: https://doi.org/10.1016/j.tmrv.2020.04.001 ter Meulen J, van den Brink EN, Poon LL, Marissen WE, Leung CS, Cox F, Cheung CY, Bakker AQ, Bogaards JA, van Deventer E, Preiser W, Doerr HW, Chow VT, de Kruif J, Peiris JS, Goudsmit J. 2006. Human monoclonal antibody combination against SARS coronavirus: synergy and coverage of escape mutants. PLOS Medicine 3 : e237. DOI: https://doi.org/10.1371/journal.pmed.0030237, PMID: 16796401

To KK, Zhang AJ, Hung IF, Xu T, Ip WC, Wong RT, Ng JC, Chan JF, Chan KH, Yuen KY. 2012. High titer and avidity of nonneutralizing antibodies against influenza vaccine antigen are associated with severe influenza. Clinical and Vaccine Immunology : CVI 19:1012-1018. DOI: https://doi.org/10.1128/CVI.00081-12, PMID: 22573737

To KK, Tsang OT, Leung WS, Tam AR, Wu TC, Lung DC, Yip CC, Cai JP, Chan JM, Chik TS, Lau DP, Choi CY, Chen LL, Chan WM, Chan KH, Ip JD, Ng AC, Poon RW, Luo CT, Cheng VC, et al. 2020. Temporal profiles of viral load in posterior oropharyngeal saliva samples and serum antibody responses during infection by SARS CoV-2: an observational cohort study. The Lancet. Infectious Diseases 20:565-574. DOI: https://doi.org/10. 1016/S1473-3099(20)30196-1, PMID: 32213337

Tseng CT, Sbrana E, Iwata-Yoshikawa N, Newman PC, Garron T, Atmar RL, Peters CJ, Couch RB. 2012. Immunization with SARS coronavirus vaccines leads to pulmonary immunopathology on challenge with the SARS virus. PLOS ONE 7:e35421. DOI: https://doi.org/10.1371/journal.pone.0035421, PMID: 22536382

van den Brink EN, Ter Meulen J, Cox F, Jongeneelen MA, Thijsse A, Throsby M, Marissen WE, Rood PM, Bakker AB, Gelderblom HR, Martina BE, Osterhaus AD, Preiser W, Doerr HW, de Kruif J, Goudsmit J. 2005. Molecular and biological characterization of human monoclonal antibodies binding to the spike and nucleocapsid proteins of severe acute respiratory syndrome coronavirus. Journal of Virology 79:1635-1644. DOl: https://doi.org/10. 1128/JVI.79.3.1635-1644.2005, PMID: 15650189

Vennema H, de Groot RJ, Harbour DA, Dalderup M, Gruffydd-Jones T, Horzinek MC, Spaan WJ. 1990. Early death after feline infectious peritonitis virus challenge due to recombinant vaccinia virus immunization. Journal of Virology 64:1407-1409. DOI: https://doi.org/10.1128/JVI.64.3.1407-1409.1990, PMID: 2154621

Walker LM, Burton DR. 2018. Passive immunotherapy of viral infections: 'super-antibodies' enter the fray. Nature Reviews Immunology 18:297-308. DOI: https://doi.org/10.1038/nri.2017.148, PMID: 29379211

Walls AC, Park YJ, Tortorici MA, Wall A, McGuire AT, Veesler D. 2020. Structure, function, and antigenicity of the SARS-CoV-2 spike glycoprotein. Cell 181:281-292. DOI: https://doi.org/10.1016/j.cell.2020.02.058, PMID: 32155444

Wan Y, Shang J, Sun S, Tai W, Chen J, Geng Q, He L, Chen Y, Wu J, Shi Z, Zhou Y, Du L, Li F. 2020. Molecular mechanism for antibody-dependent enhancement of coronavirus entry. Journal of Virology 94:e02015-e02019. DOI: https://doi.org/10.1128/JVI.02015-19, PMID: 31826992

Wang S-F, Tseng S-P, Yen C-H, Yang J-Y, Tsao C-H, Shen C-W, Chen K-H, Liu F-T, Liu W-T, Chen Y-MA, Huang JC. 2014. Antibody-dependent SARS coronavirus infection is mediated by antibodies against spike proteins. Biochemical and Biophysical Research Communications 451:208-214. DOI: https://doi.org/10.1016/j.bbrc. 2014.07.090

Wang Q, Zhang L, Kuwahara K, Li L, Liu Z, Li T, Zhu H, Liu J, Xu Y, Xie J, Morioka H, Sakaguchi N, Qin C, Liu G. 2016. Immunodominant SARS coronavirus epitopes in humans elicited both enhancing and neutralizing effects on infection in Non-human primates. ACS Infectious Diseases 2:361-376. DOI: https://doi.org/10.1021/ acsinfecolis.6b00006, PMID: 27627203

Wec AZ, Bornholdt ZA, He S, Herbert AS, Goodwin E, Wirchnianski AS, Gunn BM, Zhang Z, Zhu W, Liu G, Abelson DM, Moyer CL, Jangra RK, James RM, Bakken RR, Bohorova N, Bohorov O, Kim DH, Pauly MH, Velasco J, et al. 2019. Development of a human antibody cocktail that deploys multiple functions to confer Pan-Ebolavirus protection. Cell Host \& Microbe 25:39-48. DOI: https://doi.org/10.1016/j.chom.2018.12.004, PMID: 30629917

Wölfel R, Corman VM, Guggemos W, Seilmaier M, Zange S, Müller MA, Niemeyer D, Jones TC, Vollmar P, Rothe C, Hoelscher M, Bleicker T, Brünink S, Schneider J, Ehmann R, Zwirglmaier K, Drosten C, Wendtner C. 2020. Virological assessment of hospitalized patients with COVID-2019. Nature 581:465-469. DOI: https://doi.org/ 10.1038/s41586-020-2196-x, PMID: 32235945

Wrapp D, Wang N, Corbett KS, Goldsmith JA, Hsieh CL, Abiona O, Graham BS, McLellan JS. 2020. Cryo-EM structure of the 2019-nCoV spike in the prefusion conformation. Science 367:1260-1263. DOI: https://doi.org/ 10.1126/science.abb2507, PMID: 32075877

Wu F, Wang A, Liu M, Wang Q, Chen J, Xia LSY, Zhang Y, Xun J, Lu L, Jiang S, Lu H, Wen Y, Huang J. 2020. Neutralizing antibody responses to SARS-CoV-2 in a COVID-19 recovered patient cohort and their implications. medRxiv. DOI: https://doi.org/10.1101/2020.03.30.20047365

Yeh KM, Chiueh TS, Siu LK, Lin JC, Chan PK, Peng MY, Wan HL, Chen JH, Hu BS, Perng CL, Lu JJ, Chang FY. 2005. Experience of using convalescent plasma for severe acute respiratory syndrome among healthcare workers in a Taiwan hospital. Journal of Antimicrobial Chemotherapy 56:919-922. DOI: https://doi.org/10. 1093/jac/dki346, PMID: 16183666

Young MK. 2019. The indications and safety of polyvalent immunoglobulin for post-exposure prophylaxis of hepatitis A, rubella and measles. Human Vaccines \& Immunotherapeutics 15:2060-2065. DOI: https://doi.org/ 10.1080/21645515.2019.1621148, PMID: 31116633 
Zhang L, Zhang F, Yu W, He T, Yu J, Yi CE, Ba L, Li W, Farzan M, Chen Z, Yuen KY, Ho D. 2006. Antibody responses against SARS coronavirus are correlated with disease outcome of infected individuals. Journal of Medical Virology 78:1-8. DOI: https://doi.org/10.1002/jmv.20499, PMID: 16299724

Zhang B, Liu S, Tan T, Huang W, Dong Y, Chen L. 2020. Treatment with convalescent plasma for critically ill patients with SARS-CoV-2 infection. Chest S0012-3692:30571-30577. DOI: https://doi.org/10.1016/j.chest. 2020.03.039

Zheng Z, Monteil VM, Maurer-Stroh S, Yew CW, Leong C, Mohd-Ismail NK, Arularasu SC, Chow VTK, Rlt P, Mirazimi A, Hong W, Tan Y-J. 2020. Monoclonal antibodies for the S2 subunit of spike of SARS-CoV cross-react with the newly-emerged SARS-CoV-2. bioRxiv. DOI: https://doi.org/10.1101/2020.03.06.980037

Zhou G, Zhao Q. 2020. Perspectives on therapeutic neutralizing antibodies against the novel coronavirus SARSCoV-2. International Journal of Biological Sciences 16:1718-1723. DOI: https://doi.org/10.7150/ijbs.45123, PMID: 32226289

Zhu Z, Chakraborti S, He Y, Roberts A, Sheahan T, Xiao X, Hensley LE, Prabakaran P, Rockx B, Sidorov IA, Corti D, Vogel L, Feng Y, Kim JO, Wang LF, Baric R, Lanzavecchia A, Curtis KM, Nabel GJ, Subbarao K, et al. 2007. Potent cross-reactive neutralization of SARS coronavirus isolates by human monoclonal antibodies. PNAS 104 12123-12128. DOI: https://doi.org/10.1073/pnas.0701000104, PMID: 17620608 